\title{
The First Modern Presidential Campaign: Polling the Primary Voters for JFK
}

\author{
Bruce E. Altschuler, State University of New York at Oswego
}

By its use of television and polling in a series of contested primaries, John F. Kennedy's (JFK) 1960 campaign is considered the first modern presidential campaign. This article examines the use of surveys in Wisconsin and West Virginia to determine their importance and usefulness in his successful nomination. Was the advice of pollster Louis Harris useful in the allocation of resources? Should he have seen the problems that the campaign eventually faced, especially that of anti-Catholicism in West Virginia? And, given the advances in polling today, is JFK's experience relevant to current presidential campaigns?

With its extensive use of television and polling and dozens of contested primaries, today's presidential campaign bears little resemblance to that designed by the authors of the Constitution. Because the Constitution makes no mention of political parties, it failed to foresee the development of contested presidential nominations. But the party centered presidential campaign of the nineteenth and early twentieth century has given way to today's more candidate centered one. The nomination contest has moved from an effort to gain the support of party leaders to a large scale battle for the votes of the rank and file party (plus often significant nonparty) members as candidates put together their own personal organizations to wage a national campaign as it moves from state to state. It has been modern technology that has made this change possible. As John Aldrich $(1992,69)$ has written, "Television, polling, computerized mail lists for fund-raising and get-out-the-vote campaigns, more convenient national travel" made it possible for a candidate to successfully bypass the party in the short run "and to present himself or herself as an individual rather than as a partisan." Nor do these efforts end with success on Election Day. Presidents have increasingly been, to use Samuel Kernell's $(1993,2)$ often cited term, "going public, " which he defines as "a strategy whereby a president promotes himself and his policies by appealing to the American public for support."

In many ways, John Kennedy's 1960 candidacy marks the beginning of this modern presidential campaign. Kennedy could not have won the

BRUCe E. Altschuler is Professor and Chair of the Department of Political Science at the State University of New York at Oswego.

The American Review of Politics, Vol. 16, Summer, 1995: 185-200

(1995 The American Review of Politics 
nomination without his victories in the contested Wisconsin and West Virginia primaries which proved his popular appeal to skeptical party leaders. He was, according to David Halberstam $(1979,443)$, "the first television President. In no way could he have been elected President without television."

Perhaps the most notable development, however, was the campaign's use of polls and the role played by pollster Louis Harris in the formulation of strategy. Although Thomas Dewey, in his unsuccessful try for the 1940 Republican nomination, was the first presidential candidate to utilize private polls, it was not until Kennedy that a pollster was hired full time (Wayne 1992, 118). For Bill Kovach (1989) this was the beginning of "the changing nature of political campaigns." Harris' polls constituted "an important innovation, perhaps a deciding factor in Mr. Kennedy's victory. "According to Halberstam $(1979,448)$, "Never before in American history had a major presidential candidate so depended upon the advice and skills of a pollster, using polling much as an airline pilot uses radar to chart and comprehend what he can no longer see for himself." In his account of the 1960 election, Theodore H. White $(1961,51)$ wrote that Harris, who had first worked for Kennedy in his 1958 Senate campaign, became "a member of the inner circle" in 1960, polling "more people across the country than had ever been done by any other political analyst in American history." Even Theodore Sorensen $(1965,106)$, whose account of the campaign is more critical of Harris, agrees that "More than any previous candidate in history, Kennedy sought help from the science of opinion polling," with extensive surveys "commissioned at great expense to probe areas of weakness and strength, to evaluate opponents and issues, and to help decide on schedules and tactics."

In the modern presidential campaign, there are seven major uses of polls: (1) Deciding whether to run, (2) Candidate image, (3) Issues, (4) Key subgroup breakdowns, (5) Resource allocation, (6) Measuring progress, and (7) Leaks (Altschuler 1982). This article will focus on these uses in the two critical contested primaries in Wisconsin and West Virginia. Although only Senator Hubert Humphrey ran against Kennedy in these contests, Senators Lyndon Johnson and Stuart Symington as well as former Democratic nominee Adlai Stevenson were also in the running, hoping that the primaries would eliminate both Humphrey and Kennedy paving the way for the convention to choose one of them instead. Because most convention delegates were chosen either by caucuses or party leaders, Kennedy had to sweep the primaries in order to demonstrate the strength of his public support to them. In Wisconsin, he faced a well-known opponent from a neighboring state. West Virginia was an overwhelmingly Protestant state which he had to win to show that, contrary to the conventional wisdom at the time (based largely 
on Al Smith's defeat in the 1928 presidential election), religious prejudice was not so strong as to preclude the election of a Catholic to the presidency. Although Kennedy had decided to run well before these primaries, that use of polls is relevant to this article because he had to decide which primaries to contest. Thus, we will examine all seven uses of polls in the context of Wisconsin and West Virginia. In our conclusions, we will analyze what they tell us about the consequences of the candidate centered campaign for the modern presidency.

Accounts of the campaign provide two conflicting evaluations of Harris' role. Those written by journalists during and after the campaign argue that Harris and his polls were crucial to Kennedy's victory. According to White $(1961,93)$, Harris polled 23,000 Wisconsin voters, "not only the largest ever done in a single state but invaluable in informing his candidate of moods." Late in the Wisconsin campaign, when Humphrey began to attack Kennedy more aggressively, it was Harris who counseled restraint. The New York Times quoted from Harris' advice to the candidate (Anonymous 1960, 20):

At all costs Kennedy must avoid being looked at as a politician. Anything approximating name-calling can only hurt Kennedy. He must make every effort to resist any taunts and barbs thrown by Hubert Humphrey. Temptations inevitably will arise to slug it out with Humphrey. And slug it out Kennedy must, but on his own terms and in keeping with his positive profile.

In our terms, Harris' polls identified the strengths and weaknesses of each candidate's image as a basis for campaign strategy. Such polls and advice it is argued, helped Kennedy win the primary by a margin of 56.5 to 43.5\%. As Halberstam (1979, 451-452) put it, "there were those who thought that without it Hubert Humphrey might have won in Wisconsin."

Kennedy's larger margin (61 to 39\%) in West Virginia proved decisive in his successful campaign for the Democratic nomination. These same observers claim that Harris played an even greater role in this victory than in Wisconsin. They cite two crucial decisions-entering the primary and deciding to confront the religious issue head on.

According to White $(1961,101)$, the first poll taken for Kennedy outside of Massachusetts was a June 1958 Harris survey of West Virginia showing a 52 to $38 \%$ lead over Richard Nixon. Soon after this, Kennedy began organizing in the state. When a late 1959 poll showed a 70 to $30 \%$ lead over Humphrey, the only fear was that Humphrey might decide not to enter the primary. When he did, Kennedy also filed. Other accounts (Halberstam 1979, 448; Business Week 1960, 36) agree that Harris' favorable polls and advice that West Virginia would be a good state to prove that 
Kennedy could convince Protestants to vote for him was crucial in deciding to run there.

However, the primary proved far more difficult than expected. When polls taken three weeks before the vote showed Humphrey surging ahead, Harris suggested that Kennedy stop minimizing religion as an issue. Even though most of Kennedy's Washington advisers disagreed (Halberstam 1979, 453; White 1961, 106), the candidate took Harris' advice (Lawrence 1960, $1,29)$, emphasizing attacks on religious bigotry in his speeches and scheduling a half hour television program during which Franklin Roosevelt, Jr., asked questions about the influence of the Catholic Church should Kennedy be elected President. "Between questions, FDR Jr., summarized and then blessed Kennedy's answers," concluding that he had proven that he would be able to separate his religion from the making of policy (Jamieson 1984, 126). By this time Harris was polling daily, finding a steady shift towards Kennedy after the change in strategy (White 1961, 108-109). Thus, Harris' ability to measure Kennedy's progress is given considerable credit for the West Virginia triumph.

Recent scholarship has echoed this view. One recent book on presidential elections (Wayne 1992, 118) summarized their position, stating that Harris' polls indicated that Humphrey "was vulnerable in West Virginia and Wisconsin. On the basis of this information the Kennedy campaign decided to concentrate time, effort, and money in the Protestant states. Victories in both helped demonstrate Kennedy's broad appeal, thereby improving his chances for the nomination enormously."

In contrast to these favorable views, published accounts by other Kennedy advisers give Harris far less praise in both Wisconsin and West Virginia. Sorensen $(1965,107)$, suggests numerous problems with Harris' polls such as wording variations, wide fluctuations in results, and the failure to show the depth of religious prejudice. "They told us very little about issues-except to report such profound conclusions as the fact that many voters were in favor of greater spending in their own state, lower taxes and a balanced budget, and were opposed to communism, war and foreign aid. The Senator also felt that a pollster's desire to please a client and influence strategy sometimes unintentionally colored his analyses." Kennedy remained interested in polls but grew more skeptical during the campaign. More specifically, he blamed the loss of a Wisconsin Congressional District on a late Harris poll showing it certain but urging greater attention to an upstate district which was actually hopeless. Pierre Salinger $(1966,34)$ also believes that this poll's over optimistic prognosis in the ninth and tenth districts caused Kennedy to spend the last day in the tenth rather than the more winnable second, although in contrast to Sorensen he claims that Harris gave 
Kennedy less chance in the second, which included Madison, than the ninth and tenth. According to Salinger, "Kennedy always felt that if he had spent that last day campaigning in Madison, he might have won the Second, and therefore won the state, seven districts to three."

As for West Virginia, Sorensen $(1965,139)$ agrees that the decision to enter the primary was largely due to Harris polls showing a 70 to $30 \%$ lead against Humphrey but points to a later poll, taken immediately after the Wisconsin vote, showing Humphrey ahead by $20 \%$ as evidence of the problems with Harris' polls. Another leading adviser to Kennedy, Lawrence O'Brien $(1974,67)$, agrees, pointing out that when asked about the discrepancy, Harris explained, "rather lamely I thought," that during the first poll, most West Virginians were unaware of Kennedy's religion.

When asked about these events, Harris (1989) strongly defended himself. The decision to campaign in the upstate district in Wisconsin had nothing to do with polls but was due to the lobbying of the district's Congressman, liberal Republican Alvin O'Konski, who claimed that a visit by the candidate would enable the representative's organization to deliver the district. Harris' polls "never showed the district to be strong for JFK at all."

As for West Virginia, Harris agrees that he had underestimated the extent of religious prejudice in his first poll of that state. He argues that it was only during the Wisconsin primary that the religious issue came to the fore. "It was in Wisconsin that not only was the religious issue evident, but was the subject of national media attention." After the Wisconsin primary, Harris "virtually went to live in West Virginia, polling almost continuously." There he found that large numbers of voters opposed John Kennedy on religious grounds with many believing that if elected he would require all children to attend Catholic schools, build a tunnel under the ocean to the Vatican, and declare Catholicism the official state religion. As a result of these findings, Harris, told Kennedy that if he failed to address the religious issue directly he would lose in West Virginia. Despite the objections of both Robert and Joseph Kennedy, the candidate agreed to change his strategy. When Harris reinterviewed voters after the television appearance described above, he found many now intended to vote for Kennedy to show that West Virginians were not bigots. Harris describes this as "one of my prouder and more important polling feats."

Fortunately, many of Harris' original polling reports are now available (Kesaris 1986), enabling us to evaluate the accuracy of these conflicting claims. Wisconsin was polled thoroughly beginning with a benchmark statewide poll of 630 voters in June 1958. In order to assess whether to enter the primary, a second poll of 1200 voters was taken in April 1959. Although it showed Kennedy ahead of all his rivals, the lead was narrow enough for 
Harris to urge caution due to the proximity of Humphrey's home state of Minnesota, strong religious divisions which created the possibility of Kennedy's winning the Catholic districts while losing the Protestant ones, and the more promising nature of other states. Harris proposed polling again later in the year before making a final decision.

Harris returned in December with an even larger survey of 1549 probable primary voters. Finding that Kennedy now had a likely $60 \%$ of the vote including at least $40 \%$ of the Lutheran vote and a 7-3 Congressional District margin, Harris recommended entering the primary. According to Sorensen (1965, 133-134), Kennedy and all his advisers favored entry so this poll "was the clincher." Harris continued to poll, concentrating on the most closely contested districts. He surveyed the third and ninth in late December; the third, seventh, and ninth in early March; and the second, fifth, and tenth later in March.

How valid are Sorensen and Salinger's criticisms? A first look at Table 1 appears to indicate that Harris' polls were reasonably accurate. Polling in the First, Fourth, Sixth, and Eighth Congressional Districts was stopped after the December poll, probably because Kennedy was so far ahead. In the primary, he carried all of them easily. In the Tenth Congressional District (the O'Konski district) Harris showed Kennedy trailing with $47 \%$, extremely close to his actual $46.2 \%$ of the vote. None of the polling reports urge extra effort in that district.

\section{Table 1. Wisconsin Poll Accuracy (in percentages)}

\begin{tabular}{ccc}
\hline Congressional District & Harris Poll & Actual Vote \\
\hline 1 & 59.0 & 57.5 \\
2 & 46.0 & 48.9 \\
3 & 52.0 & 43.7 \\
4 & 69.0 & 67.6 \\
5 & 59.0 & 55.9 \\
6 & 72.0 & 62.0 \\
7 & 59.0 & 54.8 \\
8 & 71.0 & 71.0 \\
9 & 52.0 & 41.4 \\
10 & 47.0 & 46.2
\end{tabular}

Sources: The Wisconsin primary vote for JFK is reported in The New York Times (April 6, 1960); the Harris Polls are reported in Kesaris (1986). The polls for Congressional Districts 1, 4, 6 and 8 were conducted in December 1959, for Congressional Districts 3, 7 and 9 on March 7, 1960, for Congressional Districts 2, 5 and 10 on March 21, 1960. 
However, a closer look shows a consistent overestimation of Kennedy's prospects. Except for the Second and Eighth Congressional Districts, every Harris survey gave Kennedy a higher total than he actually received. In some districts this was unimportant, either because the difference was quite small and within the margin of sampling error (as in the First and Tenth) or because Kennedy was so far ahead that the exact margin mattered little (as in the Sixth where, in fairness to Harris, he had stopped polling in December 1959). However, in the Third and Ninth Congressional Districts, Kennedy lost badly despite leads in Harris' final polls. Since these polls were taken several weeks before the primary voters could have shifted their views after the survey but, given the narrowness of the margin found by Harris, one wonders why he did not return to re-interview. Instead, Harris' final (March 21) report predicted a 9-1 or 8-2 congressional district margin although he hedged his bets by writing that 6-4 "while not probable, is certainly not beyond the realm of possibility." In fact, 6-4 turned out to be the margin of victory.

Harris' performance in Wisconsin can only be given mixed reviews at best, hardly living up to the standards claimed by those who praised him. Although Harris' final report did not recommend campaigning in any districts that later proved hopeless an earlier survey had predicted victory in one (the Ninth) that Kennedy lost. Such overoptimism provides support for the critics' argument that Harris' analysis may sometimes have been affected by a desire to influence strategy and please his client. In the Second District, where Harris did reinterview, Kennedy's actual vote was closer to victory than predicted, although the difference was within the margin of sampling error. Of the three districts in which last day campaigning was consideredthe Second, Ninth, and Tenth-Harris' polls showed the second as the least promising but the actual vote in it proved to be the closest, considerably closer than the Ninth in which Harris had suggested a Kennedy win.

Since both Harris and his critics agree that he underestimated religious prejudice in West Virginia, the major question is whether he should have been able to anticipate it. David Moore $(1992,85)$ believes that techniques of polling have improved so much since 1960 that today "only the most inept of campaign pollsters would find themselves in the situation that Lou Harris did . . . the Harris polls of today, as the polls of any presidential campaign pollster, would show in advance that once voters in West Virginia learned of Kennedy's Catholicism, their support would drop." But, as Moore also points out, since all polls have limits, we need to ask in fairness, whether, with the techniques and data available to him, Harris should have been able to see the danger ahead. As in Wisconsin, he began with a June 1958 benchmark survey. Although Kennedy did well in trial heats, defeating 
Nixon 48 to $37 \%$ (slightly better than Humphrey's $45-38$ edge), $62 \%$ of those polled were unfamiliar with him. Approximately one-third of his support came from voters who did not know him but supported "a Democrat for President next time." Rather than urging caution because of this, Harris concluded "that this is a promising fact ..." since comments from those familiar with Kennedy had a seven to one favorable ratio.

Did Harris miss any danger signals? At the least, he appears to have minimized some by adding together vague comments and small percentages of favorable remarks while discounting larger percentages of potentially prejudiced voters. Among the favorable comments he cited were the one percent classified as "He's for the Union," the one percent who mentioned "He's Worked to Further Unemployment Compensation," and the one percent who liked his position on farm policy. In his report Harris wrote, "While the one per cent is not large, it must be remembered that these were all free and unaided volunteered remarks." A more significant five percent thought "He'd Make a Fine Candidate for President," which sounds more like a rationalization made by someone who expressed support for Kennedy but was unable to think of a more substantive reason. In contrast to these limited expressions of support, Kennedy's Catholicism was his strongest negative, mentioned by seven percent of those questioned. While noting that the $31 \%$ who "feel religion does matter" was "fairly high," Harris' analysis went out of its way to suggest that this was of little significance. It concluded that Kennedy lost seven percent due to his religion but that more than half of these were Republicans likely to vote for Nixon anyway. Most voters liked Kennedy and religious prejudice was decreasing in its intensity. "Certainly," wrote Harris, "there are no indications from here that under any condition should he make reference to his religion or to make an issue out of it . . . people at this juncture do not think of him first as a Catholic."

This report seems even more over optimistic than those from Wisconsin with potentially far more serious problems. Harris grasped at the most minute signs of support while minimizing considerably larger indications of danger. For example, the one percent expressions of support that Harris put so much stock in translate to four or five people out of the 465 sampled. Nor did the polling report make any mention of the Democratic primary. It included neither trial heats against the other Democrats nor analyses of their support. The relatively small margins held by both Kennedy and Humphrey against Nixon in a strongly Democratic state should have indicated that name recognition was the most important factor and that Kennedy's lead was due more to the fact that he was a Democrat than to any specific support for him as a candidate. Given that, the solid indications of religious prejudice 
would indicate that, at the least, the next poll should explore the religious issue in as much depth as possible.

Harris returned to West Virginia in January 1960. This time he used a much larger sample of 1050, reduced to 696 likely voters. In the Democratic primary, Kennedy led Humphrey 54 to $23 \%$ with the remaining $23 \%$ undecided. Harris expected Humphrey's standing to improve as he became better known but "as of now Kennedy has a comfortable margin of victory." "If the Wisconsin results are inconclusive," his report continued, "then West Virginia seems like a good testing ground for Kennedy to win a conclusive and decisive victory over Humphrey."

Once again, Harris minimized all religious danger signals. The main reason that Kennedy led was that $72 \%$ knew him compared to only $30 \%$ who were familiar with Humphrey. In his analysis of Kennedy's image, Harris concluded that "Without exception it would be hard to find a flaw in the Kennedy image as a candidate for President." Of course, there was one obvious flaw, as $19 \%$ of those interviewed cited Kennedy's religion as a negative factor but, rather than using additional questions to probe for further information, Harris argued that the positive comments about Kennedy "more than offset this negative" which was unlikely "to have any deleterious effect on the outcome of the primary." Even more surprisingly, in his analysis of key groups, he concluded that Kennedy had the support of $67 \%$ of Protestant voters by allocating the undecided in proportion to the support of those who had already made up their minds. As Herbert Asher $(1988,111)$ has written, "This is probably a reasonable decision rule when both candidates are equally well known, and when there is no reason to suspect anything unique going on among the undecideds." In West Virginia, neither of these was true. Kennedy was familiar to more than twice as many voters and Protestants were the group most likely to be anti-Catholic. Since Harris' questions on policy issues had found "no sharp deviation on the issues working in this campaign," it was most unlikely that the undecideds would not be affected by the religious issue. Given the large number of undecided voters and the early stage of the campaign during which the poll was taken, this allocation of the undecided served only to mask the possibility of anti-Catholicism among Protestant voters.

Thus, Harris' current view, that the religious issue only came to prominence as a result of news coverage of the Wisconsin primary is inconsistent with the results of his own surveys which showed a problem that would likely grow as the campaign made the voters more aware of the candidates. His April 1959 Wisconsin poll analysis had indicated the danger of different results in districts with Protestant and Catholic majorities. $\mathrm{He}$ 
should not have been so surprised when his later West Virginia polls showed a huge surge toward Humphrey, primarily due to the religious issue.

This dramatic turnaround threatened not only Kennedy's chances of gaining the nomination but also Harris's status as a pollster and adviser. According to Harris (1989), immediately after the Wisconsin primary Kennedy showed reporters the January West Virginia poll, having told his pollster:

By giving that poll to the reporters, now you and I will be in the same boat. If I win, we both win. If I lose, we both lose. Thus, we are both in the bullseye together.

As Harris put it, "Needless to say, after that episode, which was the only time in the entire campaign when he 'leaked' a poll, I virtually went to live in West Virginia, polling almost continuously."

Harris attributes his advice to Kennedy to confront the religious issue directly to these late surveys which showed him the depth of prejudice. A more cynical observer could conclude that self-preservation was at least as important since Harris' earlier polls had been a major factor in the decision to enter the primary in the first place. If Kennedy was unable to reverse the trend, Harris could easily be seen as largely responsible for the defeat. Yet, out of this need for self-preservation came a great triumph. Kennedy did change his strategy and was able to triumph in West Virginia which provided a strong push toward the presidential nomination. Had Harris not underestimated anti-Catholicism in the state, Kennedy might not have entered the primary and, after his narrower than expected win in Wisconsin, would have lacked the proof that he could attract voters in a largely Catholic state.

\section{Conclusions}

Returning to the seven uses of polls, we can now evaluate how successful each was. One of the least commented upon innovations of Kennedy's campaign was his early start. In both states, Harris began polling nearly two years before the vote. Such political intelligence gathering not only affects the decision to run, it is also crucial in deciding where to run hardest and what appeals to begin with. These early benchmark polls provide a basis for judging whether appeals are working, allowing more time to make adjustments.

Harris surveys were extremely influential in deciding which primaries to contest. In retrospect, the decision to run in the Wisconsin and West 
Virginia primaries turned out to be essential to Kennedy's winning the nomination. However, the intelligence provided by Harris surveys, especially in West Virginia, proved less than reliable. Our findings make quite clear the dangers of a superficial reading of early polls. Because most voters, especially in primaries, do not begin a serious examination of the candidates until the last few weeks or even the last few days of the campaign, trial heat results in early polls reflect name recognition much more than real candidate evaluation. Leads in these polls can easily evaporate as voters learn more about the candidates, especially in a primary where the cue of party identification is lacking. As Irving Crespi $(1989,59)$ has written, in primaries "many voters do not have voting intentions in any meaningful sense of the word until those final days before election, and even then their intentions may not be firm."

Harris' overoptimism in both Wisconsin and West Virginia was largely due to his placing too much faith in early trial heats and, especially in West Virginia, failing to probe voter attitudes deeply enough. As a result, the signs of religious prejudice, which required a deeper examination to be fully appreciated, were buried under the news of favorable trial heats until after the Wisconsin vote. Paradoxically, however, had Harris not made these errors, Kennedy would probably have skipped the West Virginia primary that proved crucial to his winning the nomination. The early polls allowed enough margin for error to permit a later shift in strategy.

The second use of polls, measuring the images of the candidates, also was significant in this campaign. However, as has been shown, the analysis was not always as sharp as it could have been. Polls can provide a more objective measure of the strengths and weaknesses of both a candidate and the opponent than more traditional sources of intelligence but, as we have seen, the analysis of the data can be subject to the same human weaknesses as can these traditional sources. Harris' failing to foresee the dangers of Kennedy's Catholicism among Protestant voters, especially in West Virginia, is a clear demonstration of this.

Samuel Popkin has argued $(1992,156)$ that as party has become less important as a cue, voters have turned more to candidates' past positions to evaluate what they will do in the future. Unfortunately, voters often have little or no information about these past positions. In such cases, "they will accept as a proxy information about the candidate's personal demographic characteristics and the groups with which he or she has associated." It is clear that this occurred in 1960. The only way for a candidate to judge how much information voters have and how they are using it is through polls (or their more recent adaptation, focus groups). Thus, the pollster's importance in the modern campaign is inevitable. This importance includes not only the 
actual poll taking and presentation of the numbers but their interpretation either by the poll taker or others within the campaign.

In these two primaries, surveys did little to measure or evaluate voter opinion on policy issues, probably because Kennedy and Humphrey had few substantive differences, making candidate image a more significant factor. However, judging from Popkin's argument, the lack of substantive policy issues is a common theme in the modern presidential campaign, especially the pre-nomination phase. Much of the current criticism of media coverage of elections stresses this point (Patterson 1989). Although Harris did far more issue polling for the general election, that campaign also focused far more on image than policy (Jacobs and Shapiro 1992).

The fourth poll use, subgroup analysis, was far less significant than it would be today. Many of the samples were too small for reliable analysis of smaller groups. The lack of computers forced a choice between speed and depth. Because measuring progress was so important to the campaign, speed was chosen over depth to allow as many polls as possible within the limited time available before each primary. Even the shift by the Kennedy campaign from national to state by state polls was considered a significant departure from past practice (Jacobs and Shapiro 1992, 13).

The fifth use, resource allocation, was less important than during the general election or than it would be during today's pre-nomination campaign. Because there were only a few contested primaries, once a candidate decided which to enter, he did not have to make significant choices between them. Nevertheless, within a state, decisions had to be made about where to campaign. Harris' Wisconsin polls played a significant part in such decisions but the results subjected him to considerable criticism. The volatility of primary electorates makes too much reliance on polls dangerous but Harris' experience does indicate some correctives. Surveys should be continued as close to the election as is practical. Candidates themselves, or at least their non-pollster advisers, also need to develop enough expertise to be able to evaluate polling reports and data independently of those taking the reports. This latter point applies to all of the uses of polls, as will be discussed below.

Measuring progress was the most significant use of polls. Without evidence showing that a dramatic change of course is necessary to avoid defeat, most campaigns will stick to their original strategy. It was only Harris' trial heat polls in West Virginia that jolted Kennedy, over the opposition of many of his advisers, into shifting strategy from ignoring the religious issue to confronting it head on. In retrospect, it is clear that this decision, more than any other, led to Kennedy's winning the presidential nomination. Whatever 
other criticisms there may be of Harris' performance, this recommendation made his services worthwhile.

The final use of polls, leaks, occurred once in these two primaries. Kennedy himself leaked a favorable January poll of West Virginia soon after the Wisconsin vote, not simply to pressure Harris but apparently to generate momentum after Wisconsin as well. However, Harris' claim that this was the only leaked poll is contradicted by other accounts of the 1960 campaign. For example, David Moore $(1992,80-81)$ writes of leaks to Joseph Alsop that resulted in a series of columns favorable to Kennedy. He also claims that Ohio Governor Michael DiSalle was convinced to withdraw his favorite son candidacy and support Kennedy after being shown several Harris polls indicating that Kennedy would defeat any candidate in Ohio, including DiSalle. Because Kennedy's strategy in the primaries was to show his popularity to the party leaders, leaked polls were a useful supplement to the then limited number of primaries. Today the leaked poll remains important to influence press coverage, potential campaign contributors, interest groups, and opponents.

Harris' experience shows both the advantages and disadvantages of the combining of the roles of pollster and adviser. The big advantage is that it gives the person who best understands the polls enough clout to communicate both good and bad news to the candidate. This is particularly important when the news is bad as a candidate's natural tendency is to believe things are going well (at least until the voters indicate otherwise on the day of the election) so advisers with stories of declining support are likely not to be believed. Because pollster-advisers are armed with statistical evidence to back up bad tidings, they are more likely to be heeded. When Harris told Kennedy that his support had declined sharply in West Virginia and that the only way to reverse this trend was to confront the religious issue directly, Kennedy listened.

However, this greater influence in the campaign is achieved at the cost of some of the poll taker's objectivity. No longer simply researchers, pollster-advisers now have a stake in having their advice taken. A constant stream of negative news is not likely to make them a welcome presence to candidates. Harris' overemphasis of the positive and neglect of the negative in his early poll interpretations may have stemmed from this need to be listened to. Sorensen's view that Harris' desire to influence strategy unintentionally colored his analysis, while exaggerated, has a kernel of truth in it. A more objective analyst might have been less optimistic in Wisconsin and more likely to see the signs of anti-Catholicism in West Virginia. Fortunately for Harris, he was able to realize his mistake before it was too late and his own evaluation that his urging of Kennedy to change his strategy 
and the resulting primary victory were "one of my prouder and most important polling feats," seems fully justified.

Since the 1960 campaign, the influence of polls and pollsters has increased dramatically. Some scholars have gone so far as to suggest that polls "have become virtually the only source of information that candidates, party leaders, and reporters use in making their strategic decisions" (Heard $1991,141)$. The 1960 campaign is clearly a move in this direction. Our case study makes it clear that there is some information that can only be gathered by polls. Patrick Caddell and Richard Wirthlin for Presidents Carter and Reagan were even more influential campaign advisers than Harris had been and, unlike Harris, continued to give advice after their candidates were elected to the presidency. Both George Bush and Bill Clinton also appear to have paid considerable attention to their pollsters during their campaigns and after being elected. Thus, it is crucial for both the public and politicians to be informed consumers of polls to be able to evaluate both the quality of the advice received and the limits of what polls, even in today's more sophisticated versions, can tell us compared to other methods of gaining information about public opinion.

During the era of the party centered campaign, these questions were less important. The candidate centered campaign, associated as it is with weakening party identification among the electorate, increases the necessity for the information and analysis provided by the poll taker. Whereas party once provided an easy shortcut for voters to decide which candidate they most agreed with, other methods have become more important. According to Popkin $(1992,153-170)$ this has increased the importance of campaigns while segmenting the electorate. In the campaign for the nomination with its confusing array of state contests, large numbers of candidates, and variety of issues, voters are likely to look for the most obvious distinctions between candidates. Thus, "each campaign attempts to organize the many splits within the electorate by setting the political agenda in the way most favorable to its own candidate" (158). Because presidents continue to go public while in office, these attempts to control the agenda become as relevant for governance as they did for election.

A major criticism of this trend is that it allows sophisticated candidates to manipulate the public (Popkin 1992, 163-166). Our case study argues against this. Harris's attempts to wish away anti-Catholicism ran smack into the reality of the West Virginia electorate. No matter how much he might have wanted to do otherwise, John Kennedy could not set an agenda that did not address the religious issue. Once he decided to confront the issue directly, he proved that leadership could move voters away from prejudice to concentrate on what most of us would consider more relevant factors. 
Only in that way was Kennedy able to change the agenda. Although one person's leadership may be another's manipulation, in this case Kennedy brought the issue into the limelight, forcing voters to consider it more rationally. That is more informative than manipulative even if Kennedy's motive was the selfish one of winning the presidency.

But if the electorate is not infinitely malleable, Kennedy's triumph in West Virginia would be hard to duplicate today. Humphrey lacked the resources to counter the far more efficient Kennedy campaign, especially in West Virginia. Nor was the issue of anti-Catholicism one on which he sought to present an opposing position. With a better organized opponent presenting a forceful alternative, today's candidate needs the intelligence of polling data virtually immediately. With only a few primaries to contest, Kennedy had the time to regroup after the disappointing victory margin in Wisconsin, rethink his strategy, and devote all his resources to West Virginia. Since then, the huge growth in the number of contested primaries, the increased number of viable candidates, and the quicker attention focused by the mass media have made such recoveries far more difficult. There rarely will be enough time to exert the kind of leadership necessary to turn around public perceptions on an issue. If you are not right the first time, there may be no second chance.

Conversely, Presidents who go public have the luxury of a four year term to exert such leadership. President Clinton's successful effort to convince Congress to pass the North American Free Trade Agreement bears considerable similarity to Kennedy's West Virginia effort. With early efforts proving unsuccessful at rounding up votes, the administration changed its strategy to confront the issue directly. They virtually converted the issue into a political campaign complete with an opponent, Ross Perot, with whom they arranged an election style debate. Just as Kennedy's strategy changed after seeing poll results, so too did that of Clinton who meets at least once a week with pollster Stan Greenberg to discuss recent data (Berke 1993). It is clear that we need to study campaigns and governance less as separate phenomena and more as parts of a continuous process.

\section{NOTE}

I would like to thank Ken Sherrill, the late Richard Styskal, and the anonymous reviewers of this journal for their helpful comments on earlier versions of this article. I am also grateful to the libraries at SUNY Oswego and Cornell University of making research materials available. 


\section{REFERENCES}

Aldrich, John. 1992. Presidential Campaigns in Party and Candidate-Centered Eras. In Matthew D. McCubbins, ed., Under the Watchful Eye: Managing Presidential Campaigns in the Television Era. Washington,D.C.: CQ Press.

Altschuler, Bruce E. 1982. Keeping a Finger on the Public Pulse: Private Polling and Presidential Elections. Westport, CT: Greenwood Press.

Anonymous. 1960. "Official Rebukes Kennedy Hecklers," The New York Times (March 23):20.

Asher, Herbert. 1988. Polling and the Public: What Every Citizen Should Know. Washington, D.C.: CQ Press.

Berke, Richard. 1993. Clinton Aide Says Polls Had Role in Health Plan. The New York Times, December 9.

Business Week. 1960. How Polls Helped Candidates (December 3):34-36.

Crespi, Irving. 1989. Public Opinion, Polls, and Democracy. Boulder: Westview Press. Halberstam, David. 1979. The Powers That Be. New York: Dell.

Harris, Louis. 1989. Letter to Author, August 7.

Heard, Alexander. 1991. Made in America: Improving the Nomination and Election of Presidents. New York: HarperCollins.

Jacobs, Lawrence R. and Robert Y. Shapiro. 1992. Issues, Candidate Image, and Priming: The Use of Private Polls in Kennedy's 1960 Presidential Campaign. Unpublished Paper.

Jamieson, Kathleen Hall. 1984. Packaging the Presidency. New York: Oxford University Press.

Kernell, Samuel. 1993. Going Public: New Strategies of Presidential Leadership. Washington, D.C.: CQ Press.

Kesaris, Paul, ed. 1986. The John F. Kennedy 1960 Campaign: Part I: Polls, Issues, and Strategy. Frederick, Md.: University Publications of America (Microfilm, Reel 1).

Kovach, Bill. 1989. Too Much Opinion, at the Expense of Fact. The New York Times (September 13):A31.

Lawrence, W.H. 1960. "Kennedy Charges 'Gang Up' by Foes," The New York Times (April 19):1, 29.

McCubbins, Matthew D., ed. 1992. Under the Watchful Eye: Managing Presidential Campaigns in the Television Era. Washington, D.C.: CQ Press.

Moore, David W. 1992. The Superpollsters. New York: Four Walls Eight Windows.

O’Brien, Lawrence. 1974. No Final Victories. Garden City, N.Y.: Doubleday.

Patterson, Thomas E. 1989. The Press and Its Missed Assignment.In Michael Nelson, ed., The Elections of 1988. Washington, D.C.: CQ Press.

Popkin, Samuel. 1992. Campaigns That Matter. In Matthew D. McCubbins, ed., Under the Watchful Eye: Managing Presidential Campaigns in the Television Era. Washington, D.C.: CQ Press.

Salinger, Pierre. 1966. With Kennedy. New York: Doubleday.

Sorensen, Theodore C. 1965. Kennedy. New York: Harper \& Row.

Wayne, Stephen J. 1992. The Road to the White House 1992: The Politics of Presidential Elections. New York: St. Martin's Press.

White, Theodore H. 1961. The Making of the President, 1960. New York: Atheneum. 